\title{
Editorial on gender affirming surgery
}

This series of Annals of Translational Medicine presents a collection of original and review articles on the current state of the art in gender affirming medicine. Over the last several years, the rate of gender affirming services has increased exponentially. This has brought a great opportunity for medical care providers to work in a multidisciplinary fashion, in order to offer different lines of treatments never provided before. This is reflected in better access and myriad opportunities for the transgender community to reach the healthcare they deserve in an expedited fashion. The opportunity to reflect upon the experience acquired in the last several years regarding clinical outcomes, research and patient satisfaction, has allowed us to standardize clinical management and, at the same time, leave room to innovate and be at the forefront in the field of transgender medicine.

We are extremely thankful to all the authors for their invaluable contributions to this series, as we gathered some of the most experienced healthcare providers in the field of transgender medicine to offer a compilation of the most current evidence-based medicine in this field.

We hope you find these manuscripts to be educational and inspiring. We believe this series will not only provide clinically relevant information to surgeons and other healthcare providers involved in transgender medicine, but will also serve as the foundation to the growth of the transgender literature.

\section{Acknowledgments}

Funding: None.

\section{Footnote}

Provenance and Peer Review: This article was commissioned by the editorial office, Annals of Translational Medicine for the series "Transgender Surgery". The article did not undergo external peer review.

Conflicts of Interest: All authors have completed the ICMJE uniform disclosure form (available at http://dx.doi.org/10.21037/ atm-21-905). The series "Transgender Surgery" was commissioned by the editorial office without any funding or sponsorship. OJM, JAP, XL served as the unpaid Guest Editor of the series. The authors have no other conflicts of interest to declare.

Ethical Statement: The authors are accountable for all aspects of the work in ensuring that questions related to the accuracy or integrity of any part of the work are appropriately investigated and resolved.

Open Access Statement: This is an Open Access article distributed in accordance with the Creative Commons AttributionNonCommercial-NoDerivs 4.0 International License (CC BY-NC-ND 4.0), which permits the non-commercial replication and distribution of the article with the strict proviso that no changes or edits are made and the original work is properly cited (including links to both the formal publication through the relevant DOI and the license). See: https://creativecommons.org/licenses/by-nc$\mathrm{nd} / 4.0 \%$. 


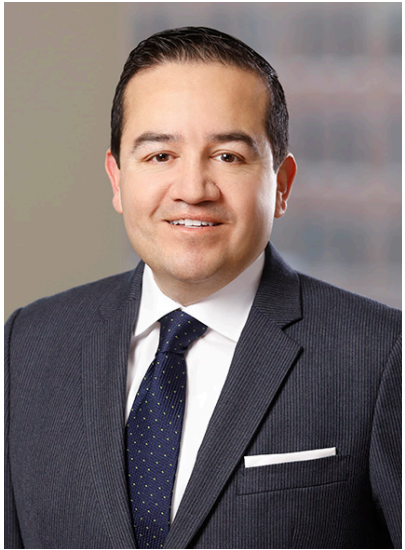

Oscar J. Manrique

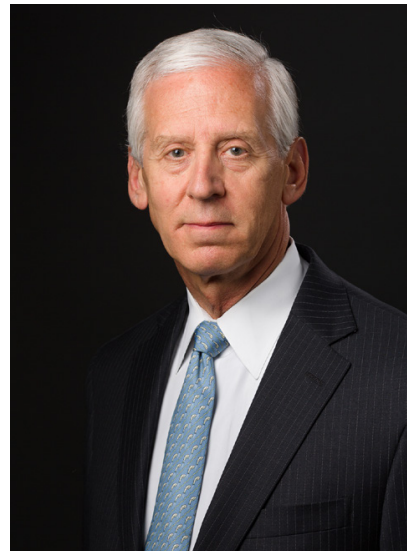

John A. Persing

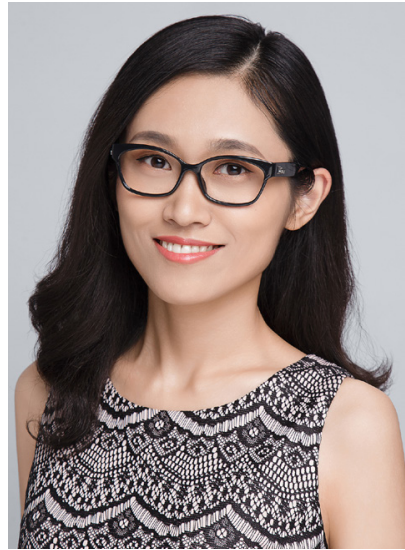

Xiaona Lu

Oscar J. Manrique ${ }^{1}$, MD, FACS

${ }^{1}$ Assistant Professor of Surgery, Division of Plastic and Reconstructive Surgery, Strong Memorial Hospital, University of Rochester Medical Center, Rochester, NY, USA. (Email: oscarj.manrique@gmail.com)

John A. Persing ${ }^{2}$, MD

${ }^{2}$ Division of Plastic and Reconstructive Surgery, Yale University School of Medicine, New Haven, Connecticut, USA.

(Email: jobn.persing@yale.edu)

Xiaona $\mathrm{Lu}^{3,4}, \mathrm{MD}, \mathrm{PhD}$

${ }^{3}$ Division of Plastic and Reconstructive Surgery, Yale University School of Medicine, New Haven, CT, USA;

${ }^{4}$ Department of Genetics, Yale University School of Medicine, New Haven, CT, USA.

(Email: xiaona.lu@yale.edu)

Submitted Feb 10, 2021. Accepted for publication Feb 26, 2021.

doi: $10.21037 / \mathrm{atm}-21-905$

View this article at: http://dx.doi.org/10.21037/atm-21-905

Cite this article as: Manrique OJ, Persing JA, Lu X. Editorial on gender affirming surgery. Ann Transl Med 2021;9(7):599. doi: 10.21037/atm-21-905 